\title{
Student Acceptance of E-Learning System During Covid-19 Pandemic
}

\author{
Laksmi Sito Dwi Irvianti ${ }^{1, *}$ Ratih Hurriyati ${ }^{2}$, Puspo Dewi Dirgantari ${ }^{3}$
}

\author{
${ }^{1}$ Universitas Pendidikan Indonesia \\ ${ }^{2}$ Universitas Pendidikan Indonesia \\ ${ }^{3}$ Universitas Pendidikan Indonesia \\ *Corresponding author. Email: laksmisito@upi.edu
}

\begin{abstract}
This study was conducted at Bina Nusantara University and had the purpose of determining the student acceptance of the e-learning system during the COVID-19 pandemic. The data used are secondary data from articles and journals and primary data collected by distributing an online questionnaire to 100 students majoring in management as a respondent with simple random sampling as sampling technique. The data collected was analyzed by using linear regression. The result showed that both perceived usefulness and perceived ease to use have a positive and relatively strong correlation with the intention to use. Furthermore, the study also showed that perceived usefulness and perceived ease to use significantly affect intention to use partially and simultaneously. Since the pandemic will last for a long time, so this study can be an input to the university to improve its e-learning system in the future.
\end{abstract}

Keywords: e-learning, intention to us, perceived of ease to use, perceived of usefulness.

\section{INTRODUCTION}

COVID-19 pandemic finally began to enter Indonesia in early March 2020 when the first Corona case was revealed. As the third week of May 2020, there have been confirmed more than 20,000 positive cases of Corona in Indonesia [1]. With the increasing number of Corona cases and the increasing number of areas that have been confirmed to have Corona cases, the university has changed its policy regarding the learning process.

Regarding the COVID-19 pandemic, Plt Dirjen DIKTI of Higher Education of the Ministry of Education and Culture urged universities to conduct elearning if there were positive cases of corona in the area near campus [2]. Related to this policy until midMarch 2020 there are 67 universities make a policy to close the campus and conduct e-learning [3].

Binus is one of the universities that has implemented e-learning policies for all learning activities, both face-to-face lectures, thesis guidance, exams, and thesis defense. Binus currently has a
Learning Management System (LMS) that supports lecturing and learning activities called Binusmaya. However, the LMS is not designed to do online lectures. Therefore, Binus, with all its limitations, is trying to facilitate the e-learning process during the Covid-19 pandemic. The term e-learning refers to the use of technology in the teaching-learning process, where the technology should increase the effectiveness of the process because it can increase the interaction between students and between students and lecturers [4]. For this reason, it is necessary to research how Binus hold the acceptance of students to the e-learning system. The purpose of this study was to determine student acceptance of the e-learning system during the COVID19 pandemic.

E-learning was defined as an educational process in which the communication in that process was conducted with electronic tools that enable elaboration and construction of knowledge [5-7]. While e-learning system, often called a virtual learning environment (VLE), was a system that uses information technology and modern communication to support education and training activities [5]. 
There are some benefits offered by e-learning system including offering information sources to students and various examples, improvement of learning quality, creating asynchronous learning network [5], cost-effectiveness, consistency, on-time content or materials, accessibility, and quick feedback [7]. We can measure the effectiveness of e-learning by using three dimensions: pedagogy, technology, and management \& learning resources [8].

Previous studies revealed that the use, success, and acceptance of information systems was measured with the model that Davis created, that was technology acceptance model (TAM), and IS success model created by Delone and McLean [6]. There was a theory that can be used to assess the acceptance of the technology. For example, diffusion of Innovation Theory [9] explained five innovation characteristics, including relative advantage, compatibility, complexity, trialability, and observability. Another theory used to measure user acceptance of the technology was the Technology Acceptance Model (TAM) that use perceived usefulness and perceived ease of use as critical variables that affect individual behavior or intention to use technology [10].

Technology Acceptance Model (TAM) was proposed by [10], in which this model explained the attitude-intention-behavior chain to understand IT acceptance and use determinants. According to Davis, individual actual behavior was based on perceived usefulness (PU) and perceived ease to use (PEU) of IT users [11]. Perceived usefulness was defined as the degree to which a person believes that using a particular system will improve its performance. While perceived ease to use refers to the degree to which the person believes that using particular will be free of effort, there is no difficulty using the system [11]. Both PU or PEU affect individual behavior towards the use of information technology, intention to use information technology, and actual use of information technology.

\section{Perceived Usefulness (PU) and Intention to Use}

Technology Acceptance Model (TAM) assumes that intention to use technology was affected by the user's perception about the usefulness of that technology. Previous studies showed that perceived usefulness correlates to technology use $[12,13]$.

$\mathrm{H} 1$ : perceived usefulness significantly affect towards intention to use the e-learning system

\section{Perceived Ease to Use (PEU) and Intention to Use}

Perceived Ease to Use refers to effort or cost spent by consumer or information technology users. When consumers or users feel that the information technology is user-friendly or if consumers or users do not have to put an extra effort into using information technology, it will increase intention to use that information technology. That statement was confirmed by some previous studies [12].

$\mathrm{H} 2$ : perceived ease to use significantly affect towards intention to use the e-learning system

The research model can be seen in fig. 1 .

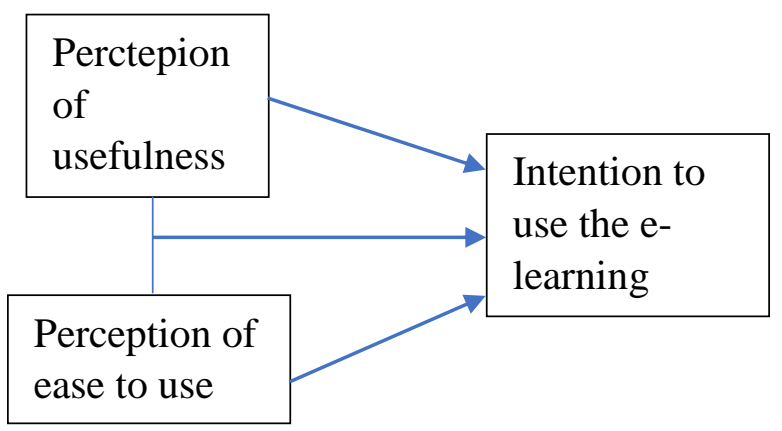

Figure 1. Research Model

\section{METHODS}

This study used secondary data collected through articles and journals and primary data by distributing the questionnaire to 100 Binus university students majoring in management as respondents. The sampling technique used was simple random sampling, in which respondents were chosen randomly from the population and had the same opportunity [14]. Because of some limitations and obstacles, the number of population was unknown, so that the number of samples was calculated using the Lemeshow formula. According to that formula, the number of samples needed for this study was 100 respondents.

Indicators of the variable were measured using the Likert scale, in which each statement had five answers to be chosen (from strongly agree to strongly disagree. Likert scale was assumed as an interval scale [14].

Data collected was analyzed using multiple regression, in which more than one independent variable was thought to affect a dependent variable [14].

\section{RESULTS AND DISCUSSION}

The model summary table shows the adjusted Rsquare value of 0.476 means the variable intention to use is explained by the variable perceived usefulness and the variable perceived ease to use by $52.4 \%$ and the rest by other factors.

Furthermore, from SPSS output, we can have a regression equation (1) as follow:

$\mathrm{Y}=0.025+0,320 \mathrm{X} 1+0.415 \mathrm{X} 2$

The equation shows that the better student's perceived usefulness, the higher the intention to use the e-learning system is, and vice versa. Moreover, the 
better student's perceived ease to use, the intention to use the e-learning system will also increase, and vice versa.

The result of the t-test shows that the t-count of PU is $2.654>\mathrm{t}$-table that is 1.98 , which means the first hypothesis is accepted or perceived of usefulness significantly affects student's intention to use e-learning system. Meanwhile, the t-value of PEU is $6.703>$ the $t-$ table that is 1.98 , which means the second hypothesis is accepted or perceived ease to use significantly affects students' intention to use e-learning system.

Based on F test table, F value > F table $(40,406>$ 3,09 ) and probability value (significance) is 0,000 . Then, Ha is accepted, which means perceived usefulness (PU) and perceived ease of use (PEU) simultaneously and significantly affects student's intention to use elearning systems.

Based on questionnaire results, Binus student's intention to use the e-learning system is good enough. COVID-19 pandemic becomes a trigger for students to take part in the e-learning system and intend to use learning management systems such as Binusmaya and other e-learning applications. However, not all students agree that the learning process conducted $100 \%$ online will be better than learning through traditional textbooks or face-to-face in class. They still need face-to-face activities to explain in more detail, accompanied by pictures or writing on the board. Besides, lectures online mean students are required to be independent, and it has not become a culture or habit for students. Overall, the student's perceived usefulness is useful, which means LMS (binusmaya) and existing online learning applications help students in lectures, especially assignments. This is because all information related to courses, including assignments, is already in binusmaya. Submitting assignments through binusmaya is felt to be very helpful by students. In general, students feel that binusmaya or other media for online lectures are easy to use because they already use binusmaya, although it is limited to viewing course outlines, discussion forums, and assignments. The obstacle that might be faced is the internet access problem.

This study's result is in line with previous studies that stated there was a positive and significant correlation between perceived usefulness and perceived ease to use $[12,13]$.

\section{CONCLUSION}

Based on the results, it can be concluded that both perceived usefulness and perceived ease to use affected student's intention to use e-learning, partially and also simultaneously

\section{REFERENCES}

[1] Infografis COVID-19 (20 Mei 2020), KPCPEN, May 20, 2020. [online] Avaible: https://covid19.go.id/p/berita/infografis-covid-1920-mei-2020

[2] Antisipasi covid-19, dikti minta kampus selenggarakan kuliah jarak jauh, Liputan 6, March 14, 2020. [Online]. Avaible: https://www.liputan6.com/news/read/4201640/antis ipasi-covid-19-dikti-minta-kampus-selenggarakankuliah-jarak-jauh.

[3] Dampak korona, kuliah online diberlakukan di 67 kampus, medcom.id, March 19, 2020. [Online]. Avaible: https://www.medcom.id/pendidikan/newspendidikan/JKRGRz3N-dampak-korona-kuliahonline-diberlakukan-di-67-kampus.

[4] Vululleh, Pee, 'Determinants of students' elearning acceptance in developing countries: an approach based on structural equation modeling (SEM)," International J. of Education and Development Using Information and Communication Technology., vol.14, no. 1, 2018.

[5] Coboa, Angel, Rochab, Rocio and RodríguezHoyosc, Carlos, "Evaluation of the interactivity of students in virtual learning environments using a multicriteria approach and data mining, Behaviour \& Information Technology," vol.33, no.10, pp. 214,2014

[6] Poelmans, S., P. Wessa, K. Milis, E. Bloemen, and C. Doom. "Usability and acceptance of e-learning in statistics education, based on the compendium platform," In Proc. The International Conference of Education, Research and Innovation, pp. 1-10, 2008. [Online]. Avaible: https://www.researchgate.net/publication/22848527 4_Usability_and_Acceptance_of_eLearning_in_Sta tistics_Education_Based_on_the_Compendium_Pla tform.

[7] Mi-Ryang, Kim, "Factors influencing the acceptance of e-learning courses for mainstream faculty in higher institutions International," J. of Instructional Technology and Distance Learning., vol. 5, no .2, 2008 .

[8] Sridharan, Bhavani, Deng, Hepu, Kirk, Joyce, and Corbitt, Brian, "Structural equation modeling for evaluating the user perceptions of e-learning effectiveness in higher education," in Proc. ECIS, 2010. [Online]. Avaible: https://aisel.aisnet.org/ecis2010/59/.

[9] Ngampornchai, Anchalee and Adam, Jonathan, 'Students' acceptance and readiness for e-learning in Northeastern Thailand," International J. of Educational Technology in Higher Education., pp. 13-34, 2016

[10] Davis, D. Fred, "Perceived usefulness, perceived ease of use, and user acceptance of information technology, MIS quarterly," September 1989. 
[11] F.D. Davis, R.P. Bagozzi, and P.R Warshaw. "User acceptance of computer technology: A comparison of two theoretical models," Management Science, vol. 35, no. 8, pp. 982-1003, 1989.

[12] Bachleda, Catherine, and Ouaaziz, Sanaa Ait, 2017, "Consumer acceptance of cloud computing, services marketing quarterly," vol 38 no.1, 2017.
[13] Mbarek, Rabeb, and Zaddem, Dr. Ferid, "The examination of factors affecting e-learning effectiveness" International J. of Innovation and Applied Studies., vol. 2, no. 4, 2013.

[14] Sekaran, Uma, and R. Bougie, "Research methods for business" in A skill-building approach, 7th edition, Chichester, West Sussex, United Kingdom : John Wiley \& Sons, 2016, pp 215-216, 2016 